change of colour and whether it is connected with any special state of the weather I have not yet determined.

Note.-Since the above was written, I have made a rough attempt to measure definitely the rate of growth of these crystals. A cylindrical stoneware bottle $3^{\cdot 6}$ inches high and 2.25 inches diameter was stuck upside down on a post 40 inches high for three hours at a time, the crystals formed on it melted down and the volume of the water measured. Assuming that the cylinder acted like a flat surface placed perpendicularly to the wind whose height and breadth are equal to its height and diameter-an assumption that appears to be very nearly true, at least for small surfaces-I find that with dense fog and strong wind (force 6 to 8 of Beaufort's scale) the rate of growth, as measured above, is about $0^{\circ} 125$ inch per hour. That is to say, if the density of the snow be one-tenth that of the water, the crystals were growing at the rate of one and a quarter inch per hour. The crystals were quite loose and feathery, and contained practically no fallen or drifted snow; all had been formed directly out of the fog.

R. T. OMOND

\section{BIRD ARCHITECTURE}

$\mathrm{T}$

$\mathrm{HE}$ way in which a bird builds its nest, seemingly without instruction, thought, or experience, has been repeatedly brought forward as a convincing proof of blind infallible instinct governing it in its task. No more popular proof has been brought forward by the supporters of the blind instinct theory than that of bird-architecture. It is thought a wonderful thing for a bird to build a nest without any instruction, or without ever seeing a nest typical of its species. That birds are capable of such marvellous powers has long ago been denied by $\mathrm{Mr}$. Wallace, and we have not a particle of evidence that such is really the case ("Nat. Selection," and Seebohm's "Brit. B.," ii. Introd.). Indeed the evidence, such as we can glean, goes far to disprove the presence of any such instinctive power. Birds brought up in confinement have been found not to make a nest typical of their species, but generally content themselves with forming a rudimentary structure-heaping a lot of material together without any design, or even laying their eggs on the bare ground with no provision at all! In my opinion, however, the conditions of life are so changed when a bird is kept in confinement that too much weight should not be attached to its actions in captivity, and the experiment has never to my knowledge fairly been tried with wild birds or birds living under normal conditions.

A remarkable instance, however, of a changed mode of nest-building has just been brought to my notice by Mr. W. Burton, the well-known naturalist of Wardour Street. Some time ago his brother: (now employed at the museum at Wellington, N.Z.) took out to New Zealand a number of young birds of our common native species, with the object of introducing them to the Antipodes. Amongst them were some young chaffinches (Fringilla calebs). These were turned out and have thriven well in a wild state, bidding fair to permanently establish this charming little bird in our distant colonies. Some of the birds have built a nest; and to Mr. Burton I am indebted for a photograph of the wonderful structure they have woven. It is evidently built in the fork of a branch, and shows very little of that neatness of fabrication for which this bird is noted in England. The materials with which it is made seem very different, too. The cup of the nest is small, loosely put together, apparently lined with feathers, and the walls of the structure are prolonged for about eighteen inches, and hang loosely down the side of the supporting branch. The whole structure bears some resemblance to the nests of the Hangnests (Icteridæ), with the exception that the cavity containing the eggs is situated on the top. Clearly these New Zealand chaffinches were at a loss for a design when fabricating their nest.
They had no standard to work by, no nests of their own kind to copy, no older birds to give them any instruction, and the result is the abnormal structure I have just described. Perhaps these chaffinchesimitated in some degree the nest of some New Zealand species; or it may be that the few resemblances this extraordinary structure presents to the typical nest of the Palæarctic chaffinch are the results of memory - the dim remembrance of the nest in which they had been reared, but which had almost been effaced by novel surroundings and changed conditions of life. Any way we have here, at last, a most interesting and convincing proof that birds do not make their nests by blind instinct, but by imitating the nest in which they were reared, aided largely by rudimentary reason and by memory. I have not the least doubt that, had these young chaffinches been hatched in an alien nest in this country, and never allowed to see a nest typical of their species, or have any connection with old and experienced birds, the results would have been still more startling and strange. Man has to learn the particular art of house-building practised by his own peculiar race -birds have to do the same! CHARLES DIXON

\section{THE INSTITUTION OF NAVAL ARCHITECTS}

THE Annual Meetings of the Institution of Naval Architects were held during the week preceding Easter at the rooms of the Society of Arts. There were five sittings, at which the necessary routine business was transacted, the presidential address of Lord Ravensworth was delivered, and seventeen papers were read and discussed. On the whole the meetings were successful and the papers of good quality, but far too much work was attempted in the time available. It is to be hoped that the growing importance of the proceedings and the improving financial position of the Institution may lead the Executive to arrange for holding regular autumnal sessions at the principal outports, in addition to the spring sessions in London.

The papers read were chiefly "papers of information," having a strictly practical or descriptive character, only two or three having scientific pretensions. Marine engineering also occupied a far more prominent place than has been usual hitherto, nearly one-half of the papers having relation to the propelling apparatus of steamships. The fact is significant, indicating the remarkable progress which has recently been made in marine engineering, and suggesting the progress which may yet be made. Of the papers coming into this group, that by Mr. Macfarlane Gray, of the Board of Trade, was the only one of a scientific nature. Mr. Gray has on more than one occasion brought his "ether-pressure" theory before the Physical Society, where it has not been well received. His recent paper "On the Theoretical Duty of Heat in the SteamEngine" was probably understood by only a few of his hearers; and Prof. Cotterill, whose authority on the subject is undoubted, was the only speaker who really contributed any useful criticism. While complimenting Mr. Gray on some of his graphic processes, and expressing admiration for his courage and perseverance, Prof. Cotterill took exception to the generalisations attempted in the paper and to the assumption that the results so far obtained were any real confirmation of the soundness of the theory advanced.

All the other engincering papers were of a practical character. The actual performances of "triple-expansion" engines as compared with the "double-expansion" or ordinary compound marine engines, were discussed at length. Experience appcars to be conclusive on the point that, by using steam of 120 to 150 pounds' pressure, and having three successive expansions in separate cylinders, an economy of from 15 to 20 per cent. in coal consumption is to be realised. This economy is of the highest importance, both in mercantile and war ships 